\title{
Nitrogen and methanogen community composition within and among three Sphagnum dominated peatlands in Scandinavia
}

\author{
Magalí Martí Generó, Heli Juottonen, Bjorn J.M. Robroek, \\ Kim Yrjälä, Åsa Danielsson, Per-Eric Lindgren and Bo Svensson
}

Linköping University Post Print

\section{Tweet}

N.B.: When citing this work, cite the original article.

Original Publication:

Magalí Martí Generó, Heli Juottonen, Bjorn J.M. Robroek, Kim Yrjälä, Åsa Danielsson, PerEric Lindgren and Bo Svensson, Nitrogen and methanogen community composition within and among three Sphagnum dominated peatlands in Scandinavia, 2015, Soil Biology and Biochemistry, (81), , 204-211.

http://dx.doi.org/10.1016/j.soilbio.2014.11.016

Copyright: Elsevier

http://www.elsevier.com/

Postprint available at: Linköping University Electronic Press

http://urn.kb.se/resolve?urn=urn:nbn:se:liu:diva-113846 


\section{Nitrogen and methanogen community composition within and among three Sphagnum dominated peatlands in Scandinavia}

Magalí Martí Generóa,d,* , Heli Juottonen ${ }^{\mathrm{b}, 1}$, Bjorn J.M. Robroek ${ }^{\mathrm{c}, 2}$, Kim Yrjälä̈, Åsa

Danielsson $^{\mathrm{a}}$, Per-Eric Lindgren ${ }^{\mathrm{d}}$, Bo H. Svensson ${ }^{\mathrm{a}}$

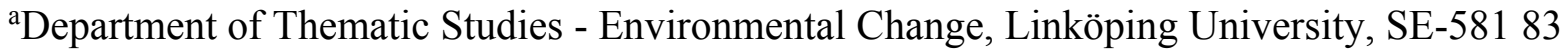

Linköping, Sweden

${ }^{b}$ MEM-group, Department of Biosciences, University of Helsinki, FIN-00014 Helsinki,

Finland

${ }^{c}$ Ecology and Biodiversity Group, Institute of Environmental Biology, Utrecht University,

Padualaan 8, $3584 \mathrm{CH}$ Utrecht, The Netherlands

${ }^{\mathrm{d} D i v i s i o n}$ of Medical Microbiology, Department of Clinical and Experimental Medicine,

Linköping University, SE-581 85 Linköping, Sweden

*Corresponding author. E-mail: magali.marti.genero@liu.se; Phone number: 00467008956

21. Address: Department of Thematic Studies - Environmental Change, Linköping

University, SE-581 83 Linköping, Sweden

Key words: Methanogenic archaea, $m c r A$ gene, Peatland, Microtopography, T-RFLP, qPCR

1 Present address: Department of Ecology and Genetics, Limnology, Uppsala University, SE-752 36 Uppsala, Sweden.

2 Permanent address: École Polytechnique Fédérale de Lausanne (EPFL), School of Architecture, Civil and Environmental Engineering (ENAC), Laboratory of Ecological Systems (ECOS), Batiment GR, Station 2, CH-1015 Lausanne, Switzerland.

E-mail addresses: magali.marti.genero@liu.se (M. Martí Generó), heli.juottonen@ebc.uu.se (H. Juottonen), b.j.m.robroek@uu.nl, bjorn.robroek@epfl.ch (B.J.M Robroek), kim.yriala@helsinki.fi (K. Yrjälä), asa.danielsson@liu.se (Å. Danielsson), per-eric.lindgren@liu.se (P. Lindgren), bo.svensson@liu.se (B.H. Svensson).

Phone numbers: 0046700895621 (M. Martí Generó), 004613282922 (Å. Danielsson), 0041216930895 (B.J.M Robroek), 003589 19159220 (K. Yrjälä), 0046101038586 (P. Lindgren), 004613282280 (B.H. Svensson). 


\section{ABSTRACT}

Ombrotrophic raised bogs are nutrient poor acidic peatlands accumulating organic matter. They are widely spread on northern latitudes and are substantial sources of methane emissions to the atmosphere being of great concern from a climate change perspective. We investigated the methanogen community composition along microtopographic gradients within three bogs in Scandinavia, receiving different amounts of nitrogen precipitation. Methanogenic community analyses by terminal restriction fragment length polymorphism of the $m c r A$ gene showed different profiles among the three sites, while no influence of the microtopographic gradients was observed. Peat temperature and dissolved organic carbon were the major edaphic variables explaining $38 \%$ of the variation of the methanogenic community diversity among the bogs. The family Methanoregulaceae (hydrogenotrophic methanogens) showed the largest relative proportion and highest activity in all three sites. Quantitative PCR of the $m c r A$ gene and transcripts showed that the most northern site, receiving the lowest atmospheric nitrogen load, had significantly lower abundance and activity of methanogens ( $4.7 \times 10^{6}$ and $2.4 \times 10^{4} \mathrm{mcr} A$ copies per gram of soil, respectively), compared to the most southern site $\left(8.2 \times 10^{7}\right.$ and $4.6 \times 10^{5} \mathrm{mcr} A$ copies per gram of soil, respectively), receiving the highest nitrogen load. No patterns of the $m c r A$ gene and transcript abundances were observed along the microtopography. The results indicated that the difference in occurrence of methanogens is mainly due to geoclimatological conditions rather than site intrinsic microtopographic variation. The study further suggests that environmental changes on the site intrinsic topography will not affect the methanogenic activity, while increasing average temperatures in Scandinavian ombrotrophic raised bogs might contribute to an increase of the methanogenic archaeal activity resulting in an increase of methane production. 


\section{INTRODUCTION}

Peatlands cover approximately $3 \%$ of the Earth's land area, but hold about $30 \%$ of the total soil carbon. This is due to a comparatively low degradation of organic matter in relation to net primary production leading to sequestration of atmospheric $\mathrm{CO}_{2}$ (Gorham, 1991). However, peatlands are also an important source of atmospheric $\mathrm{CH}_{4}$ due to production by methanogenic archaea (Eriksson et al., 2010).

Hydrology, plant functional types, and water chemistry are used to divide boreal peatlands into two types: ombrotrophic bogs and fens. The ombrotrophic bogs are mainly Sphagnum-dominated creating an acidic environment $(\mathrm{pH} \leq 4)$ and nutrient limitation, since nutrients are only provided by precipitation (Gore, 1983). Due to their location and impact by anthropogenic air pollution, peatlands are subjected to differences in nutrient supply, which then may affect the plant community and microbial community composition.

The main factors controlling the rates of methane production in peatlands are the water table fluctuations, plant functional type composition, and peat temperature and chemical characteristics (Svensson and Sundh, 1992; Granberg et al., 1999; Ward et al., 2013). The abundance of methanogens differs between areas with high and low water table, however, the variation in the methanogenic community composition among peatlands is mainly explained by peat $\mathrm{pH}$ and temperature, where the hydrogenotrophic pathway has been found to be dominant at acidic peat $\mathrm{pH}$ and low temperature (Kotsyurbenko et al., 2007; Yavitt et al., 2011). There is no consensus on the effects of peat edaphic variables on the methanogenic community composition, which rather seems to depend on the peatland type investigated and the scope of the study. Thus, it is important to include different peatland types, of which ombrotrophic bogs are the least investigated, to be able to predict how a changing climate may impact the methanogenic community responsible for the production of the greenhouse gas methane. 
The development of different microhabitats within peatlands, such as hummocks, lawns, and hollows, gives rise to spatial patterns of the environmental conditions (Robroek et al., 2014) which in turn affect methane emissions (Svensson and Roswall, 1984). In addition, these microhabitats are characterized by a different set of peat mosses and accompanying vascular plants (Saarnio et al., 1997; Rydin and Jeglum, 2006; Robroek et al., 2009) which ultimately control the quantity and quality of the organic matter available for microbial decomposition (Kettunen and Kaitala, 1996; Galand et al., 2003; Andersen et al., 2013; Jassey et al., 2013). In short, the composition of the methanogenic archaeal communities in peatlands shows a tight link with the microtopography in the peatland (Galand et al., 2003; Yavitt et al., 2011). Hence, understanding the spatial distribution of the methanogenic population along the lawn-hummock topography may reveal further insight into the regulation of the methane formation capacity linked to the carbon balance of peatlands. The predicted climate change scenario, e.g. increased variability in precipitation and increased temperature (IPCC, 2007), together with increasing N deposition loading (Phoenix et al., 2012) are believed to, directly or indirectly, affect the microtopography and the variables controlling the potential methane production. This may affect the methane emissions and the carbon allocation (Limpens et al., 2008; Luo and Weng, 2011; Jassey et al., 2013).

Our understanding of effects of edaphic variables on the distribution of peatland methanogens is growing, yet consensus is lacking. Hitherto, research on multisite or multifactor effects is still scarce. Therefore, the present study was conducted to elucidate how the methanogenic community is affected by (1) site intrinsic microclimate conditions, (2) differences in $\mathrm{N}$ deposition and (3) variation of a suite of edaphic variables. To establish a set of contrasts, where a variation of the variables can be explored, three peatland sites were chosen: 1) Lille Vildmose (LV) in Northern Jutland, Denmark, which is an area heavily affected by farming and, thus, exposed to high deposition rates of nitrogen; 2) Store Mosse 
(SM) on about the same latitude in Sweden, but with a $\mathrm{N}$ deposition at about half of that for the Jutland site; and, 3) Degerö Stormyr (DS), located in Mid Sweden, experiences much lower $\mathrm{N}$ deposition and a colder season than the southern sites. The climatic conditions are about the same for the two southern sites. Within these sites similar microtopographic microhabitats as for the plant study (Robroek et al., 2014) were selected for peat sampling, from which the $m c r A$ gene and transcript were used to determine the abundance and diversity of methanogens.

\section{MATERIALS AND METHODS}

\subsection{Sites and peat samples collection}

In July 2009, peat samples $\left(5 \mathrm{~cm}^{3}\right)$ were collected from three Sphagnum-dominated Scandinavian ombrotrophic raised bogs (Table 1). The atmospheric N deposition data corresponding to 2008 was retrieved from The European Monitoring and Evaluation Programme (EMEP). In each site, five hummock-lawn transects (microtopographic gradients) were sampled at two depths. Using a Holmen auger (Holmen, 1964) two samples were extracted from five microhabitats - north lawn (Lawn N), north hummock slope (Slope N), hummock top (Hummock), south hummock slope (Slope S) and south lawn (Lawn S) - one sample from above the water table level (Above WTL) and another from just below the water table level (Below WTL) (Figure 1). Samples were kept cold during transport to the laboratory, where they were frozen at $-20^{\circ} \mathrm{C}$ until further analysis. Water table level and $\mathrm{pH}$ were measured in the field at the sampling time. From June $12^{\text {th }}$ to September $7^{\text {th }} 2009$, temperature was recorded at $5 \mathrm{~cm}$ below the Sphagnum cover (Robroek et al., 2014). Pore water was collected in July, from which nitrate $\left(\mathrm{NO}_{3}{ }^{-}\right)$, ammonium $\left(\mathrm{NH}_{4}{ }^{+}\right)$, phosphate $\left(\mathrm{PO}_{4}{ }^{3-}\right)$ and dissolved organic carbon (DOC) were analyzed. For more details see (Robroek et al., 2014). 


\subsection{Nucleic acid extraction and reverse transcription}

Before nucleic acid extraction, peat samples were thawed overnight at $4^{\circ} \mathrm{C}$. DNA was isolated from $0.25 \mathrm{~g}$ wet peat (average water content $=1500 \pm 540(\%$ dry weight $))$ using the FastDNA ${ }^{\circledR S P I N ~ K i t ~ f o r ~ S o i l ~ a n d ~ t h e ~ F a s t P r e p ~}{ }^{\circledR}$ Instrument (MP Biomedicals, Santa Ana, CA) according to manufacturer's instructions. The extracted DNA was further purified with the OneStep ${ }^{\mathrm{TM}}$ PCR Inhibitor Removal Kit (Nordic Biolabs AB, Täby, Sweden) and stored at $-20^{\circ} \mathrm{C}$. Total RNA was isolated from $0.75 \mathrm{~g}$ wet peat using the FastRNA®Pro Soil-Direct Kit and FastPrep ${ }^{\circledR}$ Instrument (MP Biomedicals) according to manufacturer's instructions. Extracted RNA was reverse-transcribed (RT) to complementary DNA (cDNA) using the IllustraTM Ready-to-Go RT-PCR Beads (GE-Healthcare, Uppsala, Sweden). Briefly, $28 \mu 1$ of the extracted RNA was mixed with $2.5 \mu \mathrm{l}$ of $\operatorname{pd}(\mathrm{N}) 6\left(1.0 \mu \mathrm{g} \mu \mathrm{l}^{-1}\right)$ (GE-Healthcare, Uppsala, Sweden), denatured at $97^{\circ} \mathrm{C}$ for 5 min and cooled on ice. Then one Illustra Readyto-Go RT-PCR bead (GE-Healthcare, Uppsala, Sweden) and RNAse-free water were added to a final volume of $50 \mu 1$. The RT reaction consisted of $30 \mathrm{~min}$ at $42^{\circ} \mathrm{C}$ and $5 \mathrm{~min}$ at $95^{\circ} \mathrm{C}$. The RNA and cDNA were stored at $-80^{\circ} \mathrm{C}$ and $-20^{\circ} \mathrm{C}$, respectively. The DNA and RNA concentrations from each extract were measured with the Qubit fluorometer (Invitrogen, Eugene, OR, USA). DNA extraction yielded 4.1 - $47 \mathrm{ng} \mu \mathrm{l}^{-1}$ and RNA 0.4 - $59 \mathrm{ng} \mu \mathrm{l}^{-1}$.

\section{3. qPCR of $\operatorname{mcr} A$ DNA and cDNA}

The $m c r A$ DNA and cDNA partial sequences were amplified using the primer set mlas and mcrA-rev (Steinberg and Regan, 2008). Five $\mu 1$ of template (10-fold diluted DNA and non-diluted cDNA, respectively) were added to a $20 \mu 1$ reaction mixture, consisting of $1 \mathrm{X}$ SsoFast EvaGreen Supermix (Bio-Rad Laboratories, Hercules, CA) and $300 \mathrm{nM}$ of each primer, $0.3 \mathrm{M}$ of betaine and $250 \mu \mathrm{g} \mathrm{ml}^{-1}$ of BSA. The qPCR assay was performed in a 
CFX96 $^{\mathrm{TM}}$ Real-Time PCR Detection System (Bio-Rad Laboratories) with the following protocol: $30 \mathrm{~s}$ at $95^{\circ} \mathrm{C}$ followed by 40 cycles of $30 \mathrm{~s}$ at $95^{\circ} \mathrm{C}$ and $30 \mathrm{~s}$ at $55^{\circ} \mathrm{C}$. Melting curve analysis was performed after the PCR completion by increasing the temperature from 65 to $95^{\circ} \mathrm{C}$ in $0.5^{\circ} \mathrm{C}$ increments every $5 \mathrm{~s}$. PCR products detected later than the 30 cycle threshold value $(\mathrm{Ct})$, corresponding to 50 gene copies per reaction, were run on a $1.5 \%$ agarose gel. Standard curves were created from a 507-bp and a 504-bp mcrA amplicon of Methanococcus voltae PS (GenBank X07793) and Methanothermus fervidus (GenBank J03375), respectively. The amplicon was cloned into the plasmid vector pUC57 (GenScript Corporation). The plasmids were linearized using the FastDigest EcoRI enzyme (Fermentas, Vilnius, Lithuania) and the concentration of gene copies determined with the Qubit fluorometer (Invitrogen). From each plasmid, a dilution series from $2 \times 10^{6}$ to approximately 2 gene copies $\mu 1^{-1}$ was performed. The lower limit of detection was 10 gene copies per reaction mixture and the lower limit of quantification was 100 gene copies per reaction mixture. The dynamic range was $2 \times 10^{6}$ to $2 \times 10^{1}$ gene copies $\mu \mathrm{l}^{-1}$, corresponding to $10^{7}$ to $10^{2}$ gene copies per reaction mixture. Similar efficiency was obtained within all runs $(n=8)$ with a total average of $99 \%$ (SD 1.3).

Additionally, potential inhibitory effects of the peat samples were assessed. A combination of three reaction mixtures containing separately $10^{4}, 10^{2}$ and $5 \times 10^{1}$ plasmids per reaction were prepared. Five $\mu 1$ of sample negative for the $\operatorname{mcr} A$ were added to a $20 \mu 1$ of each reaction mixture, and compared to the addition of $5 \mu 1$ RNA-free water to the respective reaction mixtures. Two DNA and 53 cDNA samples were negative for the $m c r A$. No significant difference (t-test) in the quantification between the peat samples and the RNA-free water were detected at any of the spiked concentrations. Therefore, we concluded that any potential PCR inhibitors did not interfere with the qPCR assay. 
From DS, $76 \%$ of the DNA samples were quantified, while another $20 \%$ were detectable but not quantifiable. From SM 96\% of the DNA samples were quantifiable and 4\% detectable but not quantifiable. From LV all the DNA samples (100\%) were quantified (Table 2). Of the cDNA samples, $14 \%, 30 \%$ and $48 \%$ could be quantified from DS, SM and LV, respectively (Table 2). To compare the abundance of active methanogens among sites, the quantification data of the $m c r A$ transcripts were normalized to their respective DNA samples.

\subsection{T-RFLP analysis}

The DNA extracts of each replicate were pooled together prior to the PCR amplification, as with the cDNA. The $m c r A$ region was amplified using the primers mlas and mcrA-rev (Steinberg and Regan, 2008); the forward primer (mlas) was 5'-labelled with 6carboxyfluorescein (FAM). A $25 \mu 1$ reaction mix contained one Illustra PuReTaq Ready-To-

Go PCR Bead (GE Healthcare, Uppsala, Sweden), $300 \mathrm{nM}$ of each primer, $5 \mu$ l of template DNA and RNA-free water. For the cDNA, a $25 \mu 1$ reaction mix contained one Illustra PuReTaq Ready-To-Go PCR Bead (GE Healthcare), $300 \mathrm{nM}$ of each primer, $2.5 \mu 1$ of template cDNA, $250 \mu \mathrm{g} \mathrm{ml}^{-1}$ of BSA and RNA-free water. The PCR amplifications were performed in a MyCycler ${ }^{\mathrm{TM}}$ Thermal Cycler (Bio-Rad Laboratories) under the following conditions: $30 \mathrm{~min}$ at $95^{\circ} \mathrm{C}$ followed by 30 (DNA) or 40 (cDNA) cycles of $95^{\circ} \mathrm{C}$ for $30 \mathrm{~s}, 45$ $\mathrm{s}$ at $55^{\circ} \mathrm{C}$ and $30 \mathrm{~s}$ at $72^{\circ} \mathrm{C}$; and a final extension step of $7 \mathrm{~min}$ at $72{ }^{\circ} \mathrm{C}$. PCR products were visualized on $1.5 \%$ agarose gel and purified with Wizard® SV Gel and PCR Clean-Up System (Promega, Madison, WI), according to manufacturer's instruction. The purified samples were quantified with Qubit fluorometer (Invitrogen) and visualized on a 1.5\% agarose gel. Purified PCR products (5 - 15 ng DNA and 2 - 12 ng cDNA) were digested over night with the restriction endonucleases $H h a \mathrm{I}(3 \mathrm{U})$ and $M b o \mathrm{I}(3 \mathrm{U})$ (Promega). The enzymes were chosen to optimize the separation of the peatland methanogen taxa. The selection was 
based on $m c r A$ operational taxonomic units (OTUs) at 94\% nucleotide similarity cut-off formed in mothur (http://www.mothur.org) from $m c r A$ sequence data from 11 Finnish peatlands (Table S1). This resulted in 53 OTUs and a representative sequence of each was included in the final dataset for enzyme selection by the use of T-DistinctiEnz (http://www.bioinformatics.org/ docreza/cgi-bin/restriction/t DistinctiEnz.pl). The digested products were ethanol-precipitated and mixed with Hi-Di formamide and GeneScan-500 TAMRA size standard (Applied Biosystems, Foster City, CA). The samples were loaded in an ABI PRISM 310 Genetic Analyzer (Applied Biosystems) and separated by capillarity electrophoresis. Fragments from 35 to 500 bp were analyzed with Peak Scanner ${ }^{\mathrm{TM}}$ Software v1 (Applied Biosystems) according to Juottonen et al. (2008). Peaks were identified based on the $m c r A$ sequences used in enzyme selection (Table S1), additional sequence data from the same peatlands and sequences from four other boreal peatlands (unpublished data, $\mathrm{K}$. Peltoniemi and M. Kotiaho).

\subsection{Data analysis}

Statistical analyses were performed in R version 3.0.2 (Team, 2012) mainly with the ecology package vegan (Oksanen et al., 2013). A t-test was applied to determine the potential inhibitory effect of the peat samples on the qPCR reaction. For the detectable but nonquantifiable samples (ranging 10 - 100 gene copies per reaction mixture), 50 gene copies were used for the statistical analyses. The influence of the site intrinsic factors (WTL, microtopography and hummock-lawn) on $m c r A$ gene and $m c r A$ transcripts was tested with an analysis of variance using distance matrices (Adonis) with 999 permutations and Euclidean distance. To compare methanogen community diversity based on the relative peak areas of the terminal restriction fragments (T-RFs) in relation to sampling location, we applied an analysis of similarities (ANOSIM), using 999 permutations and Bray-Curtis distance 
(Ramette, 2007). Shannon diversity index $\left(H^{\prime}\right)$ was calculated from the distribution of the TRFs derived from the mcrA gene and transcripts. The Shannon index was used to compare the diversity of methanogens among the three sites (Magurran, 2004). Linear correlations between edaphic and biological variables were investigated by the use of the Pearson's correlation test. To determine which edaphic variables were the most important in explaining the variation of the methanogenic archaeal composition, we used a constrained ordination technique redundancy analysis (RDA), using Hellinger transformation, 1000 permutations and 50 iterations per step (Ramette, 2007). The diversity of the active methanogens assessed by T-RFLP of the $m c r A$ transcripts, only 22 samples $(67 \%)$ could be amplified leading to an insufficient set of data for a proper application of the ordination tests. Thus, the RDA was not applied. All results are given with median and interquartile range (IQR) and the statistic discrimination was at a significance level of 0.05 .

\section{RESULTS}

\section{1. $m$ cr $A$ gene abundance}

The sites and the water table level (WTL) had a significant influence on the abundance of methanogens (Adonis test, $\mathrm{p} \leq 0.05$ ) (Table 3). Site explained 19\% of the variation, while the WTL explained $9 \%\left(\mathrm{R}^{2}\right.$, Adonis test). Their interaction explained another 4\% (not shown). The lowest abundance of the $m c r A$ gene with a median of $4.7 \times 10^{6} \mathrm{mcr} A$ copies per gram of dry soil was found in DS. This was followed by LV with $8.2 \times 10^{7}$ mcrA copies, while the largest amount of the $m c r A$ gene was found in SM with $6.4 \times 10^{8} \mathrm{mcr} A$ copies (Figure 2). Thus, the sites covered a range of two orders of magnitude for the number of $m c r A$ gene copies. The three sites showed significantly higher abundance of methanogens below the WTL as compared to above the WTL (Table 3). In order to discriminate any effects of the site intrinsic topography, which could be masked by the site and WTL effect, the Adonis test 
was applied separately for each site, and furthermore within each site accounting for the WTL (Table 3). This analysis revealed that DS was the only site where the overall abundance of methanogens was significantly higher in the lawns $\left(3.0 \times 10^{6}\right.$ gene copies, IQR $=1.4 \mathrm{x}$ $\left.10^{8}\right)$ compared to the hummocks $\left(9.2 \times 10^{5}\right.$ gene copies, IQR $\left.=1.6 \times 10^{7}\right)$. When stratifying according to WTL, hummocks and lawns were significantly different in the abundance of methanogens in DS and LV. The above and below WTL methanogens at DS were significantly higher in the lawns compared to the hummocks. The abundance of methanogens in LV was also larger in the lawns compared to the hummocks for the above WTL methanogens, but the opposite was observed for the below WTL methanogens. No difference in abundance of the $m c r A$ gene due to the topography was found in SM peat.

\section{2. $\operatorname{mcr} A$ gene diversity}

The diversity of methanogens was assessed by T-RFLP on the $m c r A$ functional gene resulting in 12 mcr $A$ T-RFs from the peat samples (Figure 3 and 4). The T-RFs in individual samples ranged from 2 to 7 . The T-RFLP profiles differed among sites (analysis of similarity; $\mathrm{R}=0.65, \mathrm{p}=0.001)$ and no influence of the site intrinsic factors was observed. Overall, SM and LV showed similar T-RF profiles, which differed from DS (Figure 3, Figure 5). Furthermore, DS showed lower diversity followed by LV and SM, i.e. Shannon indices (average \pm standard deviation) at $0.88 \pm 0.22,1.21 \pm 0.19$ and $1.36 \pm 0.29$, respectively. The T-RFs 464, 361, 241 and 220 bp (family Methanoregulaceae, order Methanomicrobiales) and $395 \mathrm{bp}$ showed the largest occurrence and highest relative proportion (peak area \%) within and among samples, where the 464-bp T-RF was the most common of all methanogens. SM and LV were dominated by T-RFs 464 and 395 bp followed by the 226-bp T-RF (family Methanosarcinaceae, order Methanosarcinales), while DS was dominated by T-RF 464 bp 
followed by 220 bp (Figure 3). The T-RFs 376, 298 and 247 bp (order Methanocellales) were represented in low amounts.

\section{3. $m$ cr $A$ transcript abundance}

The sites, the water table level (WTL) and also the microtopography influenced the methanogenic activity, measured as $m c r A$ transcript abundance (Adonis test, $\mathrm{p} \leq 0.05$ ). These factors explained $9 \%, 4 \%$ and $3 \%$ of the variance, respectively, (Table 3 ). All interactions were significant (not shown). Together with the factors they explained 54\% of the variance. Thus, as for the $m c r A$ gene copies, further analysis of $m c r A$ transcript abundance was conducted within each site including stratification according to the WTL within each site (Table 3). The lowest abundance of active methanogens, was found in DS, followed by SM, while the largest amount of active methanogens was found in LV, with a median of $2.4 \times 10^{4}$ $\left(\mathrm{IQR}=3.2 \times 10^{5}\right), 4.9 \times 10^{4}\left(\mathrm{IQR}=7.2 \times 10^{4}\right)$ and $4.6 \times 10^{5} \mathrm{mcr} A$ copies per gram of dry soil $\left(\mathrm{IQR}=1.8 \times 10^{6}\right)$, respectively (Figure 2). The WTL and the microtopography factors only had a significant effect on the abundance of active methanogens in LV (Table 3); where the largest amount of active methanogens was found below the WTL compared to above, with a median of $1.7 \times 10^{5}$ gene copies per gram of dry soil $\left(\mathrm{IQR}=1.4 \times 10^{6}\right)$ below WTL and a median below the quantification limit. The lawns showed higher numbers of $m c r A$ transcripts with $6.7 \times 10^{4}\left(\mathrm{IQR}=4.5 \times 10^{5}\right)$ gene copies per gram of dry soil compared to the slopes and hummocks, both with a median below the quantification limit. The differences between the hummocks and lawns had a significant influence on the abundance of active methanogens in DS (as found for the $m c r A$ gene copies) and also in LV, where the quantification of the $m c r A$ transcripts was higher in lawns compared to hummocks (Table 3). When stratifying according to WTL, the hummock-lawn differences had a significant influence on the 
abundance of methanogens in DS and LV, with the same patterns as observed for the mcrA gene.

\section{4. $m c r A$ transcript diversity}

The T-RFLP on the $m c r A$ transcripts showed a total of 6 T-RFs (Figure 4). The T-RFs in individual profiles ranged from 1 to 3 . As for the $m c r A$ gene, the T-RFs 464 (family Methanoregulaceae) and $395 \mathrm{bp}$ showed the highest occurrence and relative proportion (peak area $\%$; Figure 4). In $36 \%$ of the samples the 464-bp was the only T-RF detected, the 395-bp T-RF was the only one detected in $23 \%$ of the samples and a combination of both T-RFs was detected in another $23 \%$ of the samples. In contrast to the $m c r A$ gene, the T-RFLP profiles derived from the cDNA did not differ between sites, neither in relation to the WTL nor the microtopography factors (analysis of similarity). However, DS was characterized mainly by the 464 bp T-RFs, while SM and LV showed more similar patterns (Figure 4). The Shannon diversity index (average \pm standard deviation) showed the same methanogenic diversity in DS and SM $(0.12 \pm 0.27$ and $0.11 \pm 0.33$, respectively $)$ both being lower than the diversity in $\operatorname{LV}(0.53 \pm 0.34)$

\subsection{Edaphic variables}

A redundancy analysis (RDA) was applied to elucidate if any edaphic variables, i.e. $\mathrm{pH}$, concentrations of nitrate $\left(\mathrm{NO}_{3}{ }^{-}\right)$, ammonia $\left(\mathrm{NH}_{4}{ }^{+}\right)$, total nitrogen $(\mathrm{N})$, phosphate $\left(\mathrm{PO}_{4}{ }^{3-}\right)$, dissolved organic carbon (DOC), water content (WC) and the median temperature (MedT) could explain parts of the variation in the methanogenic archaea distribution of the three sites. The RDA on $m c r A$ gene T-RFLP data in relation to the edaphic factors explained about $38 \%$ of the community variance. The first RDA axis (RDA1) explained $26 \%$ of the variance and the second RDA axis (RDA2) 12\% (Figure 5). RDA showed that variation in the methanogen 
T-RFs distribution was largely and, significantly, explained by MedT and DOC. The separation of the methanogens in DS from the methanogens in SM and LV was mainly related to MedT (Figure 5), while DOC separated SM from the other two sites (Table 1, Figure 5). Pearson's correlation showed that MedT was positively correlated with the abundance $(r=0.36, p=0.04)$ and the diversity of methanogens $(r=0.67, p<0.001)$. However, this correlation with the abundance of methanogens was weak. The abundance of methanogens further correlated with amplitude temperature $(\mathrm{r}=0.47, \mathrm{p}=0.008)$.

\section{DISCUSSION}

This study showed that the spatial variation of methanogenic archaea diversity, abundance and activity was larger among the three investigated Sphagnum-dominated ombrotrophic raised bogs than the variation governed by the site intrinsic microtopographical factors. The two sites on about the same latitude, SM and LV (Table 1) showed similar abundance, activity and diversity of methanogens, while all these characteristics were lower at the high latitude DS site. This is in accordance with the discussion forwarded by Yavitt et al. (2011) for the diversity variation found among North American peatbogs, i.e. the diversity variation may be related to geographical distances. The distance between the two southern bogs was within the range for those observed with similar diversities by Yavitt et al. (2011), while the northern site is separated by about $1000 \mathrm{~km}$ from the LI and SM sites in the present study (Table 1). In a parallel study (Robroek et al., 2014), investigating the plant composition and ecological functions, observed that the plant species richness and plant diversity variation were similar for the southern sites (LV and SM) but differed from the northern site (DS). These results indicate that geoclimatological conditions along the latitudinal gradient studied are more important than the site intrinsic microclimatology determined by the topography. This comes through in our RDA, where median temperature was the edaphic variable 
accounting for most of the methanogenic community diversity variance explanation (26\%), clearly separating the northern site from the two southern sites. Such link between methanogen diversity and temperature has also previously been found (Liu et al., 2012). Thus, temperature might be a factor involved in the development of the different peat methanogenic populations' structures. Dispersal limitation could also potentially affect the community composition. However, we believe this to have a minor effect. In support of this, it was recently shown that dispersal limitation explained only $2.1 \%$ of the deviation of soil bacterial communities (Landesman et al. 2014).

The atmospheric nitrogen deposition levels were different among the sites, with LV receiving the highest input and highest dissolved nitrogen content in the pore water followed by SM at about one third the levels and DS one order of magnitude lower (Table 1). Increased nitrogen loads drives plant composition towards vascular plants and away from Sphagnum (Eriksson et al., 2010), which in turn increases the quality of organic matter in deeper peat supplied by the vascular plant root exudates and plant leaf litter composition (Nilsson and Öquist, 2009). Although the methanogenic communities were separated by site, this was not, however, regulated by the nitrogen regimes of the peat bogs, since no direct effect of the peat nitrogen on the methanogen diversity was found. Furthermore, the range of dissolved nitrogen of the study sites (Table 1) might not be large enough to affect the occurrence and diversity of the peat methanogens. The DOC was the second most important variable, explaining the separation of the methanogenic communities between SM and LV. A similar result was obtained by Liu et al. (2012), who investigated a gradient from subtropical to alpine wetlands, revealing that temperature and DOC were the major variables explaining the methanogens diversity variance among sites (Liu et al., 2012). Although the results indicate a geoclimatological influence (mainly temperature) along the latitudinal gradient studied, several other factors such as lower total nutrient supply by precipitation at DS, 
different hydrological regimes, differences in vegetation, or decreased duration of the growth season due to increased duration of soil frost in DS, may also contribute to the differences observed. Moreover, we do not know if DS have some endemic special characteristics, resulting in a low abundance of methanogens compared to the other two sites or if it is indeed a latitudinal and geographical effect, e.g mean annual temperature was six times lower than at the other two sites (Table 1). Furthermore, no relation between vegetation and bacterial community was observed even though the vegetation type in DS differed from the other sites, which displayed larger species richness and diversity (Robroek et al., 2014).

Water saturated soils are favorable for methane production, as they form anaerobic conditions with low redox conditions suitable for the strictly anaerobic methanogens (Blodau, 2002). Consequently, we found significantly higher abundance of $m c r A$ genes below the water table level compared to above. The abundance of $m c r A$ transcripts, however, was only significantly larger below WTL in LV. The abundance of the $m c r A$ gene and transcripts between hummocks and lawns varied among sites. In SM there was no difference regardless of sampling below or above the WTL. This might be explained by the fact that in both microhabitats, the peat below the water table is water saturated, and hence edaphic variables may not differ between these microhabitats. Nevertheless, in DS larger abundance of $m c r A$ gene and transcripts was found in the lawns, disregarding the WTL. Interestingly the lawns of this site also had a higher cover of the ericoid Andromeda polifolia (Robroek et al., 2014), possibly providing easily fermentable substrates. In LV the abundance of $m c r A$ gene and transcripts were larger in the lawns above WTL but larger in hummocks below WTL. The diversity of methanogens derived from the $m c r A$ gene and transcripts showed an even distribution along the hummock-lawn topography and among the microtopographic gradients. These results indicate that the different methanogen OTUs likely display different degrees of activity. The fact that the methanogen diversity and abundance of active methanogens did not 
correlate strengthens this argument. This observation provides support for the functional redundancy concept, in which different methanogen OTUs have the same function of producing methane, but with different tolerances to micro environmental conditions. However, Godin et al. (2012) concluded, in their study, that the methanogenic community structure was a predictor of methane production during early fall, but not during spring.

Regarding the methanogen diversity distribution, a study of the methanogen community in a minerogenic oligotrophic fen by analyzing $16 \mathrm{~S}$ rDNA, concluded that topography affected the community above the WTL (at $-10 \mathrm{~cm}$ ) but not below (at $-40 \mathrm{~cm}$ ) (Galand et al., 2003). They also found that that the variation was related to both WTL and the vegetation cover. The different outcomes in relation to the influence of the topography on methanogens (Galand et al., 2003) and the present study indicate that the spatial distribution along the site intrinsic topography may differ according to peatland type. The sampling was also different in the two studies since in the 16S rDNA study the below sample was deeper or $40 \mathrm{~cm}$ below the WTL, which would make a difference in the stratified peat.

The medians of $m c r A$ gene and transcripts copy numbers found in our three sites were relatively low as compared with previously reported numbers for an ombrotrophic upland blanket peat and a blanket peat bog also using qPCR for the $m c r A$ quantification, but obtained by applying different primers (Freitag and Prosser, 2009; Freitag et al., 2010). Our study sites also showed relatively lower diversity of the $m c r A$ gene compared to minerotrophic peatlands (Galand et al., 2005; Juottonen et al., 2005; Merila et al., 2006). Those studies performed a direct comparison between peatland types and found the ombrotrophic sites to have lower methanogen diversity. The ombrotrophic bogs are acidic and nutrient poor and with lower abundance and different type of vascular plants than minerotrophic peatlands. This gives a good explanation for the lower abundance, activity and diversity of methanogens in our study. 
The family Methanoregulaceae was the most common methanogen family and showed the largest relative abundance and active proportion at all the three sites regardless of microtopography. This observation supports a previous study, which showed that Methanoregulaceae was the dominant family in two acidic peatlands (Sun et al., 2012). This family also belongs to the 'Fen cluster' originally detected by Galand et al. (2002), and this type of methanogens have later been detected in several Nordic peatlands (Galand et al., 2003; Juottonen et al., 2005; Putkinen et al., 2009). The family belongs to the order Methanomicrobiales, which produces methane by the reduction of carbon dioxide and oxidation of hydrogen (Deppenmeier, 2002; Liu and Whitman, 2008). The hydrogenotrophy has been shown to be the main pathway of methane production in acidic bogs (Horn et al., 2003; Galand et al., 2005). This fits with the $\mathrm{pH}$-driven regulation of the two methanogenic pathways observed by Kotsyurbenko et al. (2007), i.e. a shift from the hydrogenotrophic pathway to the acetoclastic took place at a $\mathrm{pH}$ of 4.7 and above. Thus, in our study sites the $\mathrm{pH}$ was around 4 (Table 1) where the occurrence of mainly Methanoregulaceae confirms the picture.

\section{CONCLUSIONS}

Overall, the methanogenic community seems to differ between different peatland types and in its susceptibility towards different environmental and peat conditions. The methanogenic community diversity, abundance and activity differed considerably among three geographically dispersed sites, yet site intrinsic microhabitats played a minor role. This indicates that the methanogen community composition is mainly affected by geoclimatological conditions. Thus, it is concluded that local small scale environmental changes will not affect the potential methane formation. Nevertheless, our results also 
indicate a strong effect of temperature on the methanogens community diversity and activity, by which northern peatlands methane potential is vulnerable to increasing temperatures.

\section{ACKNOWLEDGEMENTS}

We are grateful to all the PEATBOG project members, and especially to Nancy Dise. We are thankful to Nordic Environmental NUcleotide Network (nenun.org) for the travel grant award MM. And to the PEATLANDERS University of Helsinki grant awarded by the rector of the University HJ. and KY. This study was part of the BiodivERsA-PEATBOG project, which was funded as ERA-net project within the European Union's 6th Framework Programme, and was also partly funded by FORMAS (Dnr 215-2008-1879) and VR (3550141100).

\section{REFERENCES}

Andersen, R., Chapman, S.J., Artz, R.R.E., 2013. Microbial communities in natural and disturbed peatlands: A review. Soil Biology and Biochemistry 57, 979-994.

Blodau, C., 2002. Carbon cycling in peatlands - A review of processes and controls. Environmental Reviews 10, 111-134.

Deppenmeier, U., 2002. The unique biochemistry of methanogenesis. Progress in Nucleic Acid Research and Molecular Biology 71, 223-283.

Eriksson, T., ÖQuist, M.G., Nilsson, M.B., 2010. Production and oxidation of methane in a boreal mire after a decade of increased temperature and nitrogen and sulfur deposition. Global Change Biology 16, 2130-2144.

Freitag, T.E., Prosser, J.I., 2009. Correlation of methane production and functional gene transcriptional activity in a peat soil. Applied and Environmental Microbiology 75, 66796687. 
Freitag, T.E., Toet, S., Ineson, P., Prosser, J.I., 2010. Links between methane flux and transcriptional activities of methanogens and methane oxidizers in a blanket peat bog. FEMS Microbiology Ecology 73, 157-165.

Galand, P.E., Saarnio, S., Fritze, H., Yrjala, K., 2002. Depth related diversity of methanogen Archaea in Finnish oligotrophic fen. FEMS Microbiology Ecology 42, 441-449.

Galand, P.E., Fritze, H., Yrjala, K., 2003. Microsite-dependent changes in methanogenic populations in a boreal oligotrophic fen. Environmental Microbiology 5, 1133-1143.

Galand, P.E., Fritze, H., Conrad, R., Yrjala, K., 2005. Pathways for Methanogenesis and Diversity of Methanogenic Archaea in Three Boreal Peatland Ecosystems. Applied and Environmental Microbiology 71, 2195-2198.

Godin, A., McLaughlin, J.W., Webster, K.L., Packalen, M., Basiliko, N., 2012. Methane and methanogen community dynamics across a boreal peatland nutrient gradient. Soil Biology and Biochemistry 48, 96-105.

Gore, A.J.P., 1983. Ecosystems of the world, 4B: Mires: swamp, bog, fen, and moor. Regional studies. Elsevier Scientific Publishing, Amsterdam, The Netherlands.

Gorham, E., 1991. Northern peatlands: role in the carbon cycle and probable responses to climatic warming. Ecological Applications 1, 182-195.

Granberg, G., Grip, M., Ottosson, L., Sundh, I., Svensson, B.H., Nilsson, M., 1999. A simple model for simulation of water content, soil frost, and soil temperatures in boreal mires. Water resources research 35, 3771-3782.

Holmen, H., 1964. Forest Ecological Studies on Drained Peat Land in the Province of Uppland, Sweden. Studia Forestalia Suecica 16, 1-236. 
Horn, M.A., Matthies, C., Kusel, K., Schramm, A., Drake, H.L., 2003. Hydrogenotrophic Methanogenesis by Moderately Acid-Tolerant Methanogens of a Methane-Emitting Acidic Peat. Applied and Environmental Microbiology 69, 74-83.

IPCC, 2007. The physical science basis summary for policymakers. In Contribution of Working Group I to the Fourth Assessment report of the IPCC.

Jassey, V.E., Chiapusio, G., Binet, P., Buttler, A., Laggoun-Defarge, F., Delarue, F., Bernard, N., Mitchell, E.A., Toussaint, M.L., Francez, A.J., Gilbert, D., 2013. Above- and belowground linkages in Sphagnum peatland: climate warming affects plant-microbial interactions. Global Change Biology 19, 811-823.

Juottonen, H., Galand, P.E., Tuittila, E.-S., Laine, J., Fritze, H., Yrjala, K., 2005. Methanogen communities and Bacteria along an ecohydrological gradient in a northern raised bog complex. Environmental Microbiology 7, 1547-1557.

Juottonen, H., Tuittila, E.-S., Juutinen, S., Fritze, H., Yrjälä, K., 2008. Seasonality of rDNAand rRNA-derived archaeal communities and methanogenic potential in a boreal mire. The ISME Journal 2, 1157-1168.

Kettunen, A., Kaitala, V., 1996. Cross-correlation analysis of the dynamics of methane emissions from a boreal peatland. Global Biogeochemical Cycles 10, 457-471.

Kotsyurbenko, O.R., Friedrich, M.W., Simankova, M.V., Nozhevnikova, A.N., Golyshin, P.N., Timmis, K.N., Conrad, R., 2007. Shift from acetoclastic to H2-dependent methanogenesis in a west Siberian peat bog at low $\mathrm{pH}$ values and isolation of an acidophilic Methanobacterium strain. Applied and Environmental Microbiology 73, 2344-2348. 
Landesman, W.J., Nelson, D.M., Fitzpatric, M.C., 2014. Soil properties and tree species drive ß-diversity of soil bacterial communities. Soil Biology and Biochemistry 76, 201-209.

Limpens, J., Berendse, F., Blodau, C., Canadell, J.G., Freeman, C., Holden, J., Roulet, N., Rydin, H., Schaepman-Strub, G., 2008. Peatlands and the carbon cycle: from local processes to global implications - a synthesis. Biogeosciences 5, 1475-1491.

Liu, D., Ding, W., Jia, Z., Cai, Z., 2012. The impact of dissolved organic carbon on the spatial variability of methanogenic archaea communities in natural wetland ecosystems across China. Appl Microbiol Biotechnol 96, 253-263.

Liu, Y., Whitman, W.B., 2008. Metabolic, phylogenetic, and ecological diversity of the methanogenic archaea. New York Academy of Sciences 1125, 171-189.

Luo, Y., Weng, E., 2011. Dynamic disequilibrium of the terrestrial carbon cycle under global change. Trends in Ecology \& Evolution 26, 96-104.

Magurran, A.E., 2004. Measuring biological diversity. Blackwell, Oxford.

Merila, P., Galand, P.E., Fritze, H., Tuittila, E.S., Kukko-Oja, K., Laine, J., Yrjala, K., 2006. Methanogen communities along a primary succession transect of mire ecosystems. FEMS Microbiology Ecology 55, 221-229.

Nilsson, M., Öquist, M., 2009. Partitioning Litter mass Loss Into Carbon Dioxide and Methane in Peatland Ecosystems. Geophysical Monograph 184, 131-144.

Oksanen, J., Guillaume Blanchet, F., Kindt, R., Legendre, P., Minchin, P.R., O'Hara, R.B., Simpson, G.L., Solymos, P., Henry, M., Stevens H., Wagner, H., 2013. vegan: Community Ecology Package. R package version 2.0-9. 
Phoenix, G.K., Emmett, B.A., Britton, A.J., Caporn, S.J.M., Dise, N.B., Helliwell, R., Jones, L., Leake, J.R., Leith, I.D., Sheppard, L.J., Sowerby, A., Pilkington, M.G., Rowe, E.C., Ashmore, M.R., Power, S.A., 2012. Impacts of atmospheric nitrogen deposition: responses of multiple plant and soil parameters across contrasting ecosystems in long-term field experiments. Global Change Biology 18, 1197-1215.

Putkinen, A., Juottonen, H., Juutinen, S., Tuittila, E.S., Fritze, H., Yrjala, K., 2009. Archaeal rRNA diversity and methane production in deep boreal peat. FEMS Microbiol Ecol 70, 8798.

Ramette, A., 2007. Multivariate analyses in microbial ecology. FEMS Microbiology Ecology $62,142-160$.

Robroek, B.J.M., Schouten, M.G.C., Limpens, J., Berendse, F., Poorter, H., 2009. Interactive effects of water table and precipitation on net $\mathrm{CO} 2$ assimilation of three cooccurringSphagnummosses differing in distribution above the water table. Global Change Biology 15, 680-691.

Robroek, B.J.M., Wubs, J.E.R., Martí, M., Zając, K., Palsgaard Andersen, J., Andersson, A., Börjesson, G., Bragazza, L., Dise, N.B., Joost A. Keuskamp, Larsson, M., Lindgren, P.-e., Mattiasson, P., solomonsson, J., Sundberg, C., Svensson, B.H., Verhoeven, J.T.A., 2014. Microclimatological consequences for plant and microbial composition in Sphagnumdominated peatlands. Boreal environmental research 19, 195-208.

Rydin, H., Jeglum, J.K., 2006. The Biology of Peatlands. Oxfor University Press. Saarnio, S., Alm, J., Silvola, J., Lohila, A., Nykänen, H., Martikainen, P.J., 1997. Seasonal variation in $\mathrm{CH} 4$ emissions and production and oxidation potentials at microsites on an oligotrophic pine fen. Oecologia 1997, 414-422. 
Steinberg, L.M., Regan, J.M., 2008. Phylogenetic Comparison of the Methanogenic Communities from an Acidic, Oligotrophic Fen and an Anaerobic Digester Treating Municipal Wastewater Sludge. Applied and Environmental Microbiology 74, 6663-6671.

Sun, C.L., Brauer, S.L., Cadillo-Quiroz, H., Zinder, S.H., Yavitt, J.B., 2012. Seasonal changes in methanogenesis and methanogenic community in three peatlands, new york state. Front Microbiol 3, 81.

Svensson, B.H., Roswall, T., 1984. In situ methane production rom acid peat in plant communities with differen moistureregimes in a subartic mire. OIKOS 43, 341-350.

Svensson, B.H., Sundh, I., 1992. Factors affecting methane production in peat soils. Suo 43, $1-8$.

Team, R.D.C., 2012. R: A language and environment for statistical computing. R Foundation for Statistical Computing, Vienna, Austria.

Ward, S.E., Ostle, N.J., Oakley, S., Quirk, H., Henrys, P.A., Bardgett, R.D., 2013. Warming effects on greenhouse gas fluxes in peatlands are modulated by vegetation composition. Ecol Lett $16,1285-1293$.

Yavitt, J.B., Yashiro, E., Cadillo-Quiroz, H., Zinder, S.H., 2011. Methanogen diversity and community composition in peatlands of the central to northern Appalachian Mountain region, North America. Biogeochemistry 109, 117-131. 
Table 1: Study sites description. Variables values are given by mean \pm standard deviation (Robroek et al., 2014).

\begin{tabular}{lccc}
\hline Site & $\begin{array}{c}\text { Degerö Stormyr } \\
(\mathrm{DS})\end{array}$ & $\begin{array}{c}\text { Store Mosse National Park } \\
(\mathrm{SM})\end{array}$ & $\begin{array}{c}\text { Lille Vildmose } \\
(\mathrm{LV})\end{array}$ \\
\hline Location & $\begin{array}{c}\text { Northern Sweden } \\
\text { Coordinates (UPS) }\end{array}$ & $\begin{array}{c}\text { Southern Sweden } \\
57^{\circ} 16^{\prime} \mathrm{N}, 13^{\circ} 55^{\prime} \mathrm{E}\end{array}$ & $\begin{array}{c}\text { Denmark } \\
56^{\circ} 50^{\prime} \mathrm{N}, 10^{\circ} 11^{\prime} \mathrm{E}\end{array}$ \\
$\begin{array}{l}\text { Atmospheric nitrogen } \\
\text { deposition }\left(\mathrm{kg} \mathrm{N} \mathrm{ha}^{-1} \mathrm{yr}^{-1}\right)\end{array}$ & 1.5 & 7.0 & 25 \\
pH & $3.96 \pm 0.19$ & $3.98 \pm 0.03$ & $3.96 \pm 0.06$ \\
$\mathrm{DOC}\left(\mathrm{mg} \mathrm{l}^{-1}\right)$ & $61.4 \pm 6.5$ & $57.4 \pm 4.7$ & $64.9 \pm 2.8$ \\
$\mathrm{NO}_{3}{ }^{-}\left(\mathrm{mg} \mathrm{l}^{-1}\right)$ & $0.03 \pm 0.01$ & $0.02 \pm 0.01$ & $0.03 \pm 0.02$ \\
$\mathrm{NH}_{4}{ }^{+}\left(\mathrm{mg} \mathrm{l}^{-1}\right)$ & $0.28 \pm 0.23$ & $0.33 \pm 0.08$ & $0.18 \pm 0.14$ \\
$\mathrm{PO}_{4}{ }^{3-}\left(\mu \mathrm{f} \mathrm{l}^{-1}\right)$ & $2.80 \pm 1.39$ & $2.88 \pm 0.40$ & $4.60 \pm 2.26$ \\
${\mathrm{Peat} \mathrm{temperaure}\left({ }^{\circ} \mathrm{C}\right)}^{\text {Mean annual temperature }\left({ }^{\circ} \mathrm{C}\right)}$ & $13.4 \pm 0.2$ & $15.4 \pm 0.6$ & $16.0 \pm 0.8$ \\
\hline
\end{tabular}


Table 2: Number and percentage (in parenthesis) of quantifiable (Q), below quantification limit (BQ) and below detection limit (BD) samples per site for qPCR of $m c r A$ gene and transcript.

\begin{tabular}{lcccccc}
\hline & \multicolumn{3}{c}{$m c r A$ gene } & \multicolumn{3}{c}{$m c r A$ transcript } \\
\hline Site & $\mathrm{Q}$ & $\mathrm{BQ}^{\mathrm{a}}$ & $\mathrm{BD}^{\mathrm{b}}$ & $\mathrm{Q}$ & $\mathrm{BQ}^{\mathrm{a}}$ & $\mathrm{BD}^{\mathrm{b}}$ \\
Degerö Stormyr & $38(76)$ & $10(20)$ & $2(4)$ & $7(14)$ & $16(32)$ & $27(54)$ \\
Store Mosse & $48(96)$ & $2(4)$ & 0 & $15(30)$ & $23(46)$ & $12(24)$ \\
Lille Vildmose & $50(100)$ & 0 & 0 & $24(48)$ & $12(24)$ & $14(28)$ \\
Total & $136(91)$ & $12(8)$ & $2(1)$ & $46(31)$ & $51(34)$ & $53(35)$ \\
\hline
\end{tabular}

${ }^{a}$ below quantification limit (between $10-100$ gene copies per reaction mixture).

${ }^{\mathrm{b}}$ below detection limit $(<10$ gene copies per reaction mixture).

Table 3: $\mathrm{R}^{2}$-values from Adonis test of the $m c r A$ gene and the $m c r A$ transcript in relation to macro (site) and site intrinsic factors (WTL,

Microtopography, Hummock-lawn). Significance codes are: $* * * p \leq 0.001,{ }^{* *} \mathrm{p} \leq 0.01,{ }^{*} \mathrm{p} \leq 0.05$. 


\begin{tabular}{|c|c|c|c|c|c|c|c|c|c|c|c|}
\hline \multirow{2}{*}{ Factor } & \multirow{2}{*}{ Nucleic Acid } & \multirow{2}{*}{$\begin{array}{c}\text { All } \\
\text { factors }\end{array}$} & & & & \multicolumn{6}{|c|}{ Split by Site and WTL ${ }^{a}$} \\
\hline & & & \multicolumn{3}{|c|}{ Split by Site } & \multicolumn{3}{|c|}{ above $\mathrm{WTL}^{\mathrm{a}}$} & \multicolumn{3}{|c|}{ below WTL ${ }^{\mathrm{a}}$} \\
\hline WTL & $m c r A$ gene & $0.09 * * *$ & $0.07 *$ & $0.10 *$ & $0.51 * * *$ & & & & & & \\
\hline Microtopography & $m c r A$ gene & $\mathrm{ns}^{\mathrm{b}}$ & $\mathrm{ns}^{\mathrm{b}}$ & $\mathrm{ns}^{\mathrm{b}}$ & $\mathrm{ns}^{\mathrm{b}}$ & $\mathrm{ns}^{\mathrm{b}}$ & $\mathrm{ns}^{\mathrm{b}}$ & $\mathrm{ns}^{\mathrm{b}}$ & $\mathrm{ns}^{\mathrm{b}}$ & $\mathrm{ns}^{\mathrm{b}}$ & $\mathrm{ns}^{\mathrm{b}}$ \\
\hline Hummock-lawn & mcrA gene & $\mathrm{ns}^{\mathrm{b}}$ & $0.09 * *$ & $\mathrm{~ns}^{\mathrm{b}}$ & $\mathrm{ns}^{\mathrm{b}}$ & $0.07 * *$ & $\mathrm{~ns}^{\mathrm{b}}$ & $0.09 * *$ & $0.07 * *$ & $\mathrm{~ns}^{\mathrm{b}}$ & $0.09 * *$ \\
\hline Microtopography & $m c r A$ transcript & $0.03 *$ & $n s^{b}$ & $n s^{b}$ & $0.11 *$ & $\mathrm{~ns}^{\mathrm{b}}$ & $\mathrm{ns}^{\mathrm{b}}$ & $\mathrm{ns}^{\mathrm{b}}$ & $\mathrm{ns}^{\mathrm{b}}$ & $\mathrm{ns}^{\mathrm{b}}$ & $\mathrm{ns}^{\mathrm{b}}$ \\
\hline Hummock-lawn & $m c r A$ transcript & $\mathrm{ns}^{\mathrm{b}}$ & $0.07 *$ & $n s^{b}$ & $0.05 *$ & $0.06 *$ & $\mathrm{~ns}^{\mathrm{b}}$ & $0.25 *$ & $0.06 *$ & $\mathrm{~ns}^{\mathrm{b}}$ & $0.25 * *$ \\
\hline
\end{tabular}

${ }^{a}$ WTL denotes Water Table Level.

${ }^{\mathrm{b}} \mathrm{ns}$ denotes non significant results. 
Figure 1: Scheme of the microtopographic gradient. Two samples were extracted from five microhabitats - North lawn (Lawn N), North hummock slope (Slope N), hummock top (Hummock), South hummock slope (Slope S) and South lawn (Lawn S) - one sample from above the water table level (WTL) and another from just below the WTL.

Figure 2: Quantification of the $m c r A$ gene (grey boxes) and $m c r A$ transcripts (white boxes) in each site. n: total number of quantified samples. DS: Degerö Stormyr; SM: Store Mosse; LV: Lille Vildmose. Significance codes of effects are: $* * * p \leq 0.001,{ }^{*} p \leq 0.05$ (Tukey’s multiple comparison test).

Figure 3: Proportion of the total T-RFs peak area percentage derived from the DNA. Top: samples from above the water table level; Below: samples from below the water table level. DS: Degerö Stormyr; SM: Store Mosse; LV: Lille Vildmose. Error bars show the standard error of the mean.

Figure 4: Proportion of the total T-RFs peak area percentage derived from the mRNA. Top: samples from above the water table level; Below: samples from below the water table level. DS: Degerö Stormyr; SM: Store Mosse; LV: Lille Vildmose. Error bars show the standard error of the mean.

Figure 5: Ordination diagram of the significant explanatory edaphic factors related to the methanogen T-RFs distribution among the three sites. MedT: media temperature. DOC: dissolved organic carbon. White: Degerö Stormyr; Grey: Store Mosse; Black: Lille Vildmose. 
Hummock Top

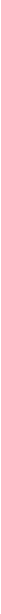




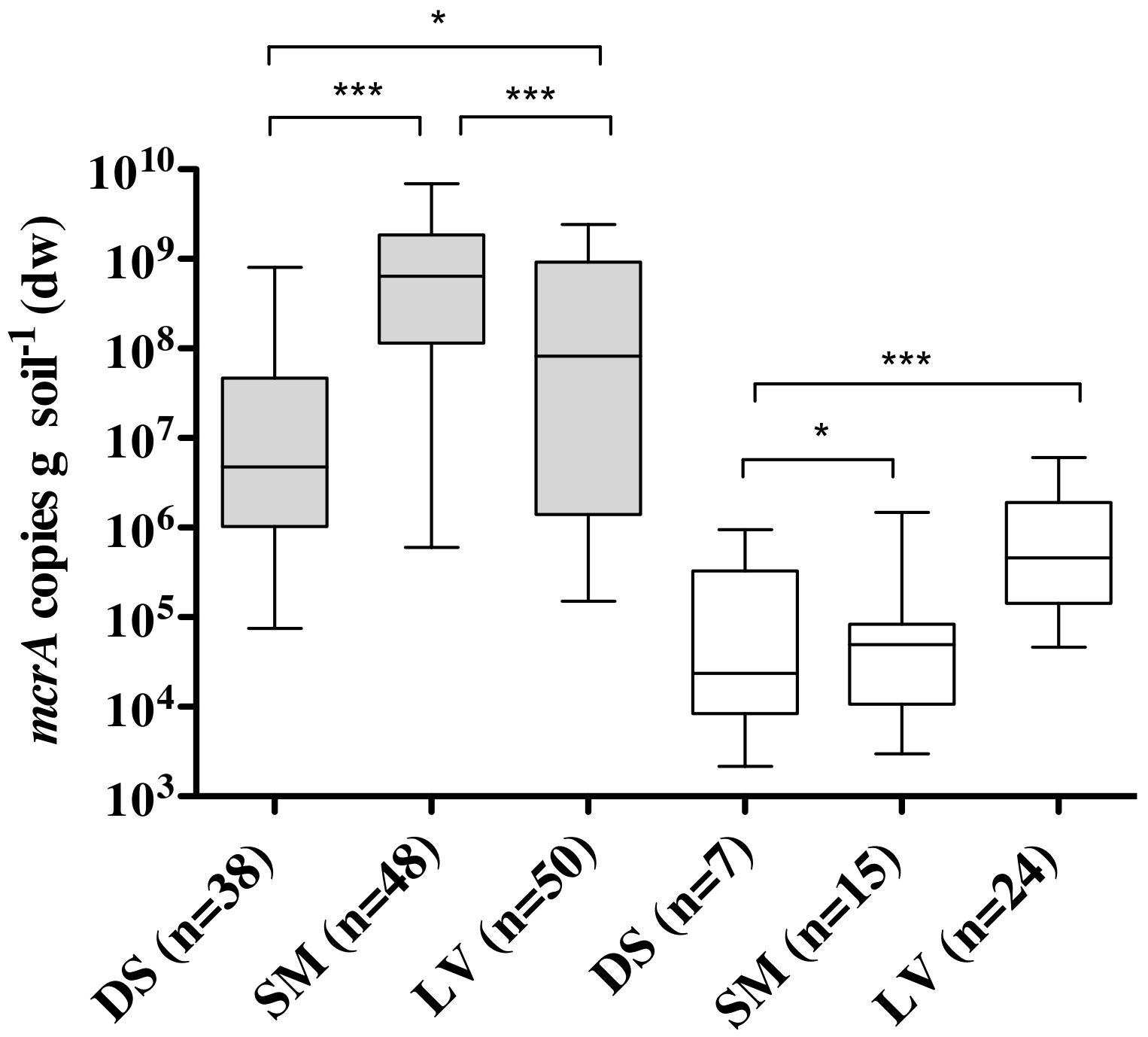



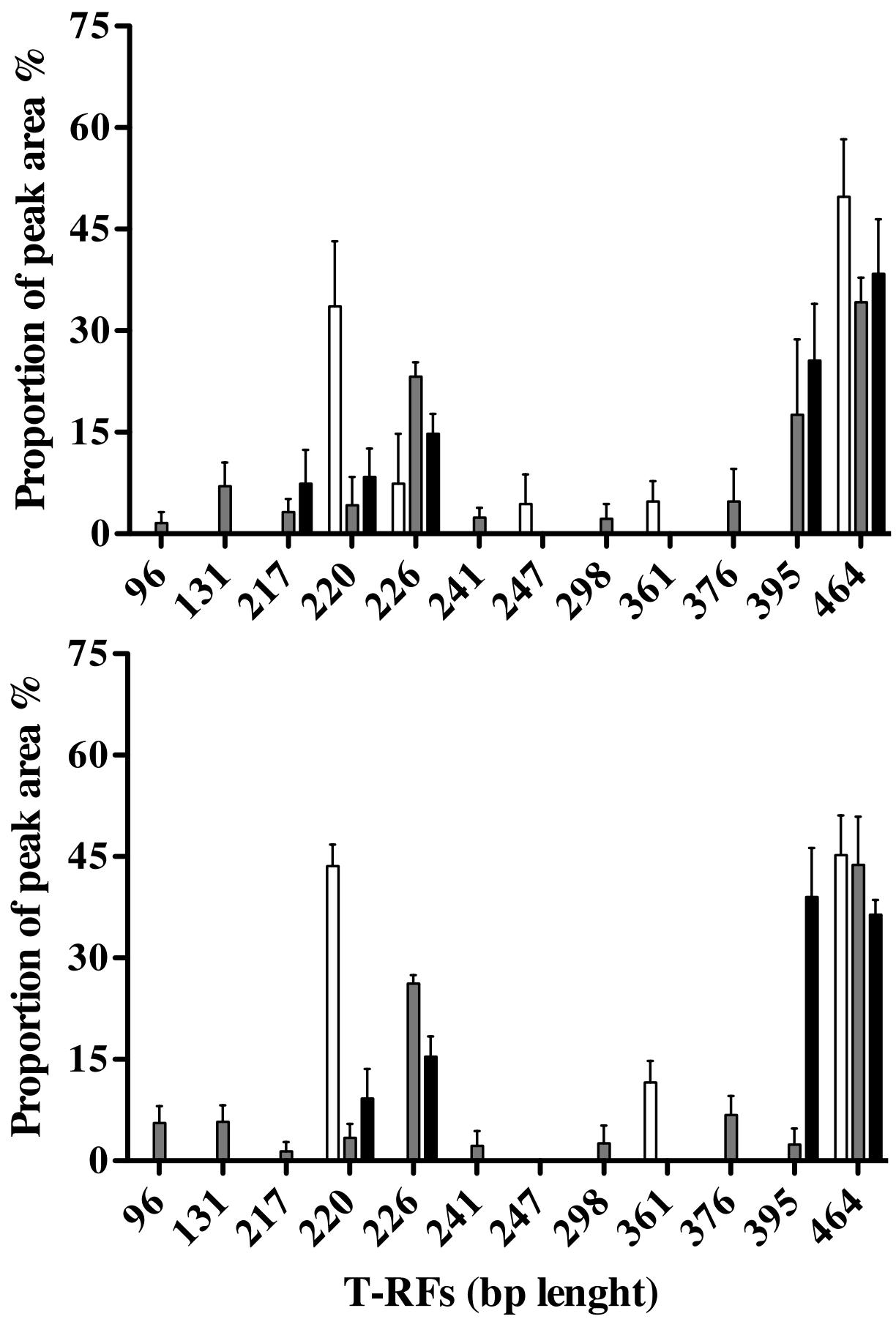


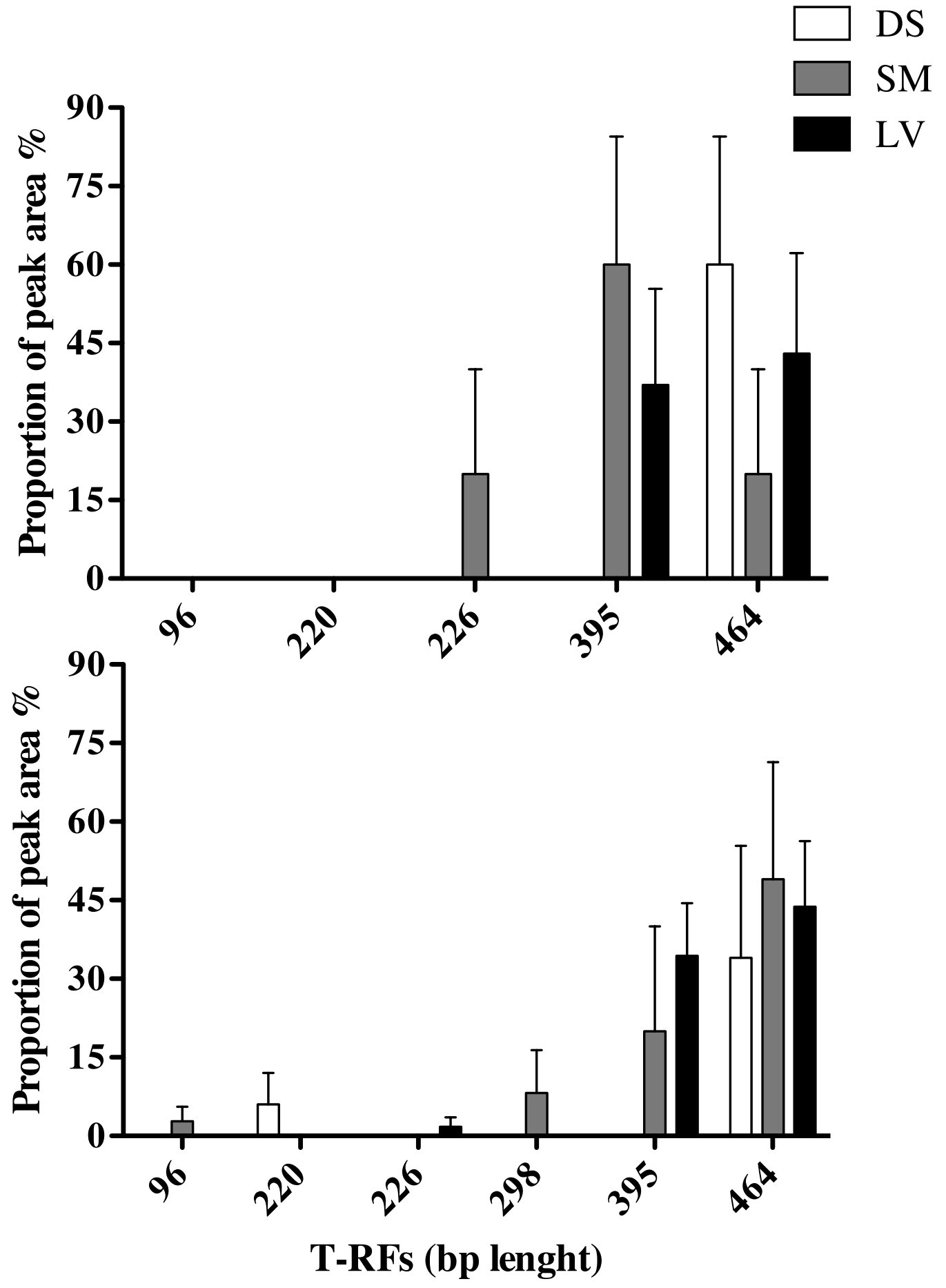




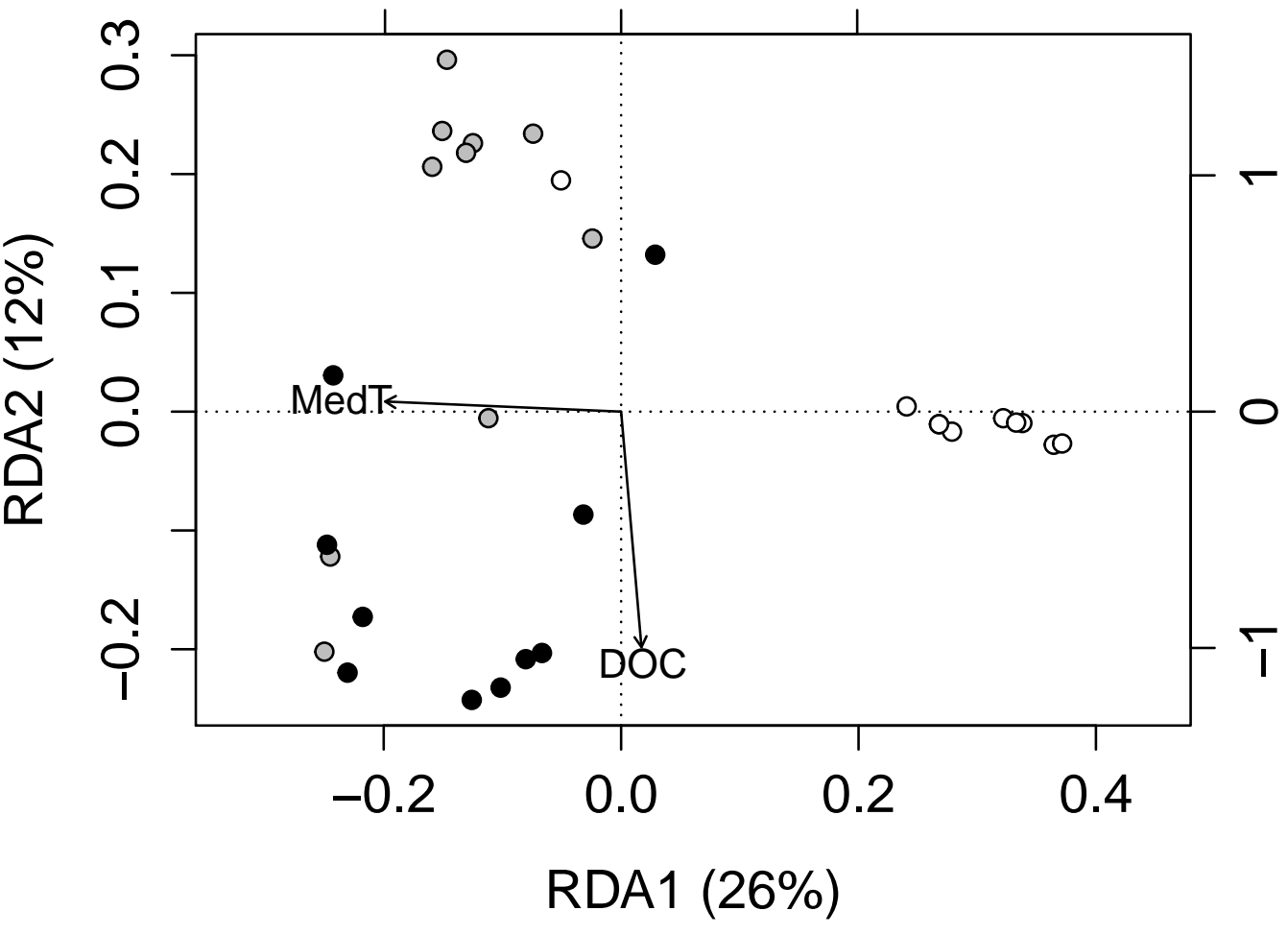

